\title{
Uniform magnetic excitations in NiO nanoparticles
}

\author{
Bahl, C.R.H.; Lefmann, K.; Kuhn, L.T.; Lindgård, P.-A.; Mørup, S.
}

Published in:

Final programme and abstract book

Publication date:

2005

Document Version

Publisher's PDF, also known as Version of record

Link back to DTU Orbit

Citation (APA):

Bahl, C. R. H., Lefmann, K., Kuhn, L. T., Lindgård, P-A., \& Mørup, S. (2005). Uniform magnetic excitations in $\mathrm{NiO}$ nanoparticles. In Final programme and abstract book (pp. 229-229). ICNS.

\section{General rights}

Copyright and moral rights for the publications made accessible in the public portal are retained by the authors and/or other copyright owners and it is a condition of accessing publications that users recognise and abide by the legal requirements associated with these rights.

- Users may download and print one copy of any publication from the public portal for the purpose of private study or research.

- You may not further distribute the material or use it for any profit-making activity or commercial gain

- You may freely distribute the URL identifying the publication in the public portal

If you believe that this document breaches copyright please contact us providing details, and we will remove access to the work immediately and investigate your claim. 


\section{Uniform Magnetic Excitations in $\mathrm{NiO}$ nanoparticles}

Christian R.H. Bahl ${ }^{1}$, Kim Lefmann ${ }^{1}$, Luise Theil Kuhn ${ }^{1}$, Per-Anker Lindgård ${ }^{1}$, Steen Mørup ${ }^{2}$

1 Materials Research Department, Risø National Laboratory, DK-4000 Roskilde, Denmark

2 Department of Physics, Technical University of Denmark, DK-2800 Lyngby, Denmark

$\mathrm{NiO}$ is a textbook antiferromagnet, and was one of the first materials in which antiferromagnetism was studied by neutron scattering. However nanoparticles of $\mathrm{NiO}$ exhibit spin dynamics that is different from bulk samples. Due to the finite size, the spin wave spectrum will be quantised. The lowest level $(q=0)$ is a coherent precession of the spin around the magnetic anisotropy easy axis, a uniform magnetic excitation. The energy spacing between such precession states is below $1 \mathrm{meV}$ and almost constant so it will give rise to inelastic resonance peaks, which can be described well by a damped harmonic oscillator model.

The NiO nanoparticles that have been studied are platelet shaped, with a diameter of $\sim 10 \mathrm{~nm}$ and a thickness of $\sim 3 \mathrm{~nm}$. They have been found to have a large amount $\left(\sim 500 \mu_{\mathrm{B}}\right)$ of uncompensated spins in one of the sublattices.

The dissimilarity of the two sublattices has a surprisingly strong impact on the magnetic resonance. Even a modest amount of uncompensated spins will split the spin dynamics into different modes, changing the energy spacings between the precession states. Studying the uniform magnetic excitations thus yields an understanding of the spin dynamics in antiferromagnetic nanoparticles with large uncompensated moments. 